\title{
Magnitude and distribution of trunk stresses in telecommunications engineers
}

\author{
A S NICHOLSON, P R DAVIS, AND N J SHEPPARD
}

From the Materials Handling Research Unit, Robens Institute of Industrial and Environmental Health and Safety, University of Surrey, Guildford, Surrey, UK

ABSTRACT The incidence of back injuries has been shown to be greater in occupations defined as heavy manual work than light manual work. To plan a programme aimed at reducing the incidence of back injuries in industry those workers at high risk of incurring handling accidents and back injuries need to be identified and a knowledge of the specific occupational factors causing such injuries sought. This has been achieved for telecommunications engineers using epidemiological and radio pressure pill methodologies. The results verify the correlation between the back injury rates and physical work stresses of different occupational groups. The magnitude and relative frequency of trunk stresses in hazardous tasks has been determined and compared with those with lower incidences of back disorders. The study has confirmed that in examining manual handling hazards in industrial male populations a critical value of truncal stress can be applied and used to determine the safety of occupational factors in relation to their potential for causing or contributing to degenerative back disease.

It is widely recognised that low back ailments and disorders are a major source of disability, discomfort, and distress to a large proportion of the population. It has recently been estimated ${ }^{1}$ that as a nation we lose $19 \cdot 2$ million working days each year because of back pain. Many studies have shown that the incidence of back disorders is greater in occupations defined as heavy manual work than in light industry and that hard physical work promotes the appearance of degenerative back disease. ${ }^{2-11}$ It is because of these observations that there is an increasing demand in industry for training in safe and efficient methods of manual materials handling. Despite concerted efforts in certain industries to reduce the incidence of industrially related back injuries, it has remained remarkably constant. Probably general handling training is insufficient, and careful identification and consideration of those workers particularly at risk of incurring handling accidents and back injuries and a knowledge of the specific occupational factors contributing to such pathologies is necessary before any programme of preventive action can be effectively applied.

In a previous study ${ }^{12}$ a detailed analysis of accident

Received 7 November 1980

Accepted 5 February 1981 morbidity in the British telecommunication industry was undertaken to determine those groups of workers in terms of their occupations, ages, and experience at greatest risk of incurring manual handling accidents, back injuries, and back injuries specifically attributed to handling accidents. Twenty-three duty codes or occupational groups were found to have accident rates significantly greater $(p<0.05)$ than the overall accident rate. Further it was found that these "top 23" duty codes, which constitute only $33 \%$ of the engineer's population, suffer $70 \%$ of all reportable accidents-that is, accidents causing absence from work for three days or longer. It was therefore concluded that in searching for the occupational factors giving rise to these accidents that most benefit could be obtained from studying the work methods of these top 23 groups.

\section{Method}

Detailed field observations of these 23 high risk groups were carried out over a 12-month period beginning in the summer months of 1978. A preliminary observation period of half a day of all the top 23 duties was carried out first to gain an understanding of the type of work and activities in which the engineers were engaged. The men were asked to carry out their 
normal duties and were questioned in order to provide information regarding other aspects of their job. For 12 of the top 23 duty codes-that is, those found to have back injury rates greater than the mean back injury rate of the top 23-a second observation period was carried out to quantify the truncal stresses incurred by the engineers while carrying out their normal duties. The duration of this observation was determined by the various activities that the engineer performed but generally lasted from onehalf to one full day.

The methodology for measuring truncal stresses was developed by the materials handling research unit and is based on observations by Davis ${ }^{13}$ and Morris et $\mathrm{al}^{14}$ and others that during lifting and other manual handling activities there is a close correlation between the magnitude of stress on the trunk and the magnitude of intra-abdominal pressure (IAP) in men. The technique requires the engineer to swallow a calibrated radio pressure pill ${ }^{15}$ and to carry out his duties while his IAP is measured.
In some cases the measurement period did not adequately cover a sufficient range of all possible activities, and a third observation period was arranged and measurements made in the same manner to cover the occupational tasks performed. When those activities found to be inducing high IAPs were identified, a further observation and measurement period was arranged to study more closely the factors contributing to these stressful activities and to test alternative work procedures to reduce the truncal stresses incurred.

\section{Results}

During the 42 periods of observation IAP measurements were made of a wide variety of the occupational tasks performed throughout the duty codes. These measurements were accumulated into common activity groups (table 1). With tasks requiring repeated actions, such as digging, the frequency of actions was counted and is also presented in this

Table 1 Accumulated results of intra-abdominal pressure measurements for various occupational tasks recorded during field studies

\begin{tabular}{|c|c|c|c|c|c|c|c|c|c|c|}
\hline \multirow[t]{2}{*}{ Activity } & \multicolumn{10}{|c|}{ Intra-abdominal pressure measurements $(\mathrm{mm} \mathrm{Hg})$} \\
\hline & Mean & $S T D D E V$ & $N o \geqslant 30$ & $N o \geqslant 50$ & $N o \geqslant 90$ & $N o \geqslant 120$ & $N o \geqslant 150$ & Rate/min & $\begin{array}{l}\text { No of men } \\
\text { concerned }\end{array}$ & $\begin{array}{l}\text { No of } \\
\text { observation } \\
\text { periods }\end{array}$ \\
\hline Pole handling & $76 \cdot 56$ & $19 \cdot 36$ & 41 & 38 & 11 & - & 一 & - & 1 or 2 & 1 \\
\hline Air bottle handling & $75 \cdot 40$ & $40 \cdot 32$ & 50 & 35 & 15 & 9 & 1 & 一 & & 3 \\
\hline Out of manhole & $123 \cdot 64$ & $35 \cdot 44$ & 11 & 11 & 9 & 6 & 1 & - & 2 & 1 \\
\hline In and out of vehicle & $61 \cdot 79$ & 30.04 & 39 & 24 & 6 & 3 & - & - & 1 or 2 & 3 \\
\hline Cover and joint box handling & $74 \cdot 31$ & $33 \cdot 41$ & 129 & 92 & 41 & 11 & 3 & - & & 6 \\
\hline "Silent Knights" & $80 \cdot 36$ & $41 \cdot 85$ & 47 & 34 & 18 & 7 & 3 & - & 1 or 2 & 3 \\
\hline "Elkingtons" & $71 \cdot 29$ & $25 \cdot 54$ & 14 & 11 & 3 & 1 & - & - & 2 & 1 \\
\hline Other types & $70 \cdot 63$ & $27 \cdot 85$ & 67 & 47 & 20 & 3 & - & - & 1 or 2 & 4 \\
\hline All 2-man handling & $77 \cdot 40$ & $33 \cdot 82$ & 113 & 85 & 39 & 11 & 3 & - & 2 & 5 \\
\hline All 1-man handling & $52 \cdot 50$ & $20 \cdot 10$ & 16 & 7 & 2 & - & - & - & 1 & 2 \\
\hline Water pump handling & $72 \cdot 48$ & $36 \cdot 36$ & 106 & 77 & 25 & 11 & 5 & 一 & & 6 \\
\hline 1 man field situation & $89 \cdot 46$ & $39 \cdot 88$ & 56 & 49 & 23 & 11 & 5 & - & 1 & 4 \\
\hline 2 man field situation & 60.91 & $11 \cdot 86$ & 22 & 19 & 1 & - & 一 & - & 2 & 3 \\
\hline 1 man stores situation & $53 \cdot 00$ & $16 \cdot 29$ & 15 & 9 & 1 & - & - & - & 1 & 1 \\
\hline 2 man stores situation & $40 \cdot 00$ & $4 \cdot 36$ & 13 & 一 & - & 一 & - & - & 2 & 1 \\
\hline Handling cable drums & $62 \cdot 40$ & $17 \cdot 05$ & 48 & 36 & 2 & - & - & 一 & 1 or 2 & 3 \\
\hline Generator handling & $59 \cdot 60$ & $22 \cdot 86$ & 20 & 12 & 3 & - & - & - & 1 & 2 \\
\hline Gas bottle handling & $58 \cdot 56$ & $20 \cdot 64$ & 37 & 23 & 4 & 一 & - & - & 1 or 2 & 6 \\
\hline Rodding and cabling & $54 \cdot 35$ & $21 \cdot 29$ & 146 & 75 & 12 & 1 & - & 25 & & 3 \\
\hline Stoop posture & $56 \cdot 78$ & $21 \cdot 37$ & 129 & 74 & 12 & 1 & - & 24 & 1 & 3 \\
\hline Kneeling posture & $36 \cdot 00$ & $6 \cdot 82$ & 17 & 1 & - & - & - & 26 & 1 & 1 \\
\hline Battery handling & $52 \cdot 24$ & $18 \cdot 78$ & 29 & 13 & 2 & - & - & - & 1 & 2 \\
\hline Trailer handling & $52 \cdot 09$ & $20 \cdot 07$ & 58 & 25 & 3 & 1 & - & - & $2+$ & 2 \\
\hline Digging activities & $45 \cdot 06$ & $13 \cdot 85$ & 697 & 196 & 9 & - & - & 22 & & 4 \\
\hline Short-handled shovel & $63 \cdot 69$ & $14 \cdot 88$ & 48 & 40 & 3 & - & 一 & 33 & 1 & 1 \\
\hline Long-handled shovel & $58 \cdot 29$ & $16 \cdot 21$ & 45 & 29 & 2 & - & - & 17 & 1 & 1 \\
\hline Ordinary spade & $47 \cdot 11$ & $15 \cdot 91$ & 108 & 35 & 4 & - & - & 20 & 1 & 3 \\
\hline Ordinary shovel & $43 \cdot 41$ & $12 \cdot 30$ & 78 & 23 & - & - & - & 23 & 1 & 1 \\
\hline Other eg cutting turfs & $42 \cdot 00$ & $12 \cdot 01$ & 37 & 8 & - & 一 & - & 15 & 1 & 2 \\
\hline Forking & $41 \cdot 65$ & $10 \cdot 36$ & 382 & 70 & - & - & - & 19 & 1 & 2 \\
\hline Long-handled spade & $39 \cdot 65$ & $7 \cdot 99$ & 63 & 9 & - & - & - & 29 & 1 & 1 \\
\hline Ladder handling & $40 \cdot 68$ & $8 \cdot 37$ & 68 & 11 & - & - & - & - & 1 & 3 \\
\hline Wiring joints & $25 \cdot 55$ & $5 \cdot 45$ & 3 & - & - & - & - & - & 1 & 1 \\
\hline Light bricklaying & $20 \cdot 84$ & $5 \cdot 41$ & 3 & - & - & - & - & - & 1 & 1 \\
\hline Working up poles, masts etc & $20 \cdot 56$ & $5 \cdot 51$ & 2 & - & - & - & - & - & 1 & 1 \\
\hline Light underground cabling & $19 \cdot 27$ & 3.08 & 1 & - & - & - & - & - & 1 & 1 \\
\hline
\end{tabular}

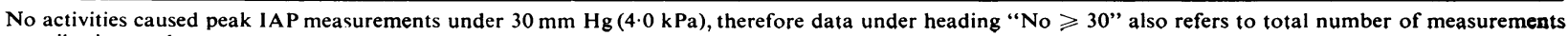
contributing to the means. 
Table 2 Digest of occupational tasks performed by duty code

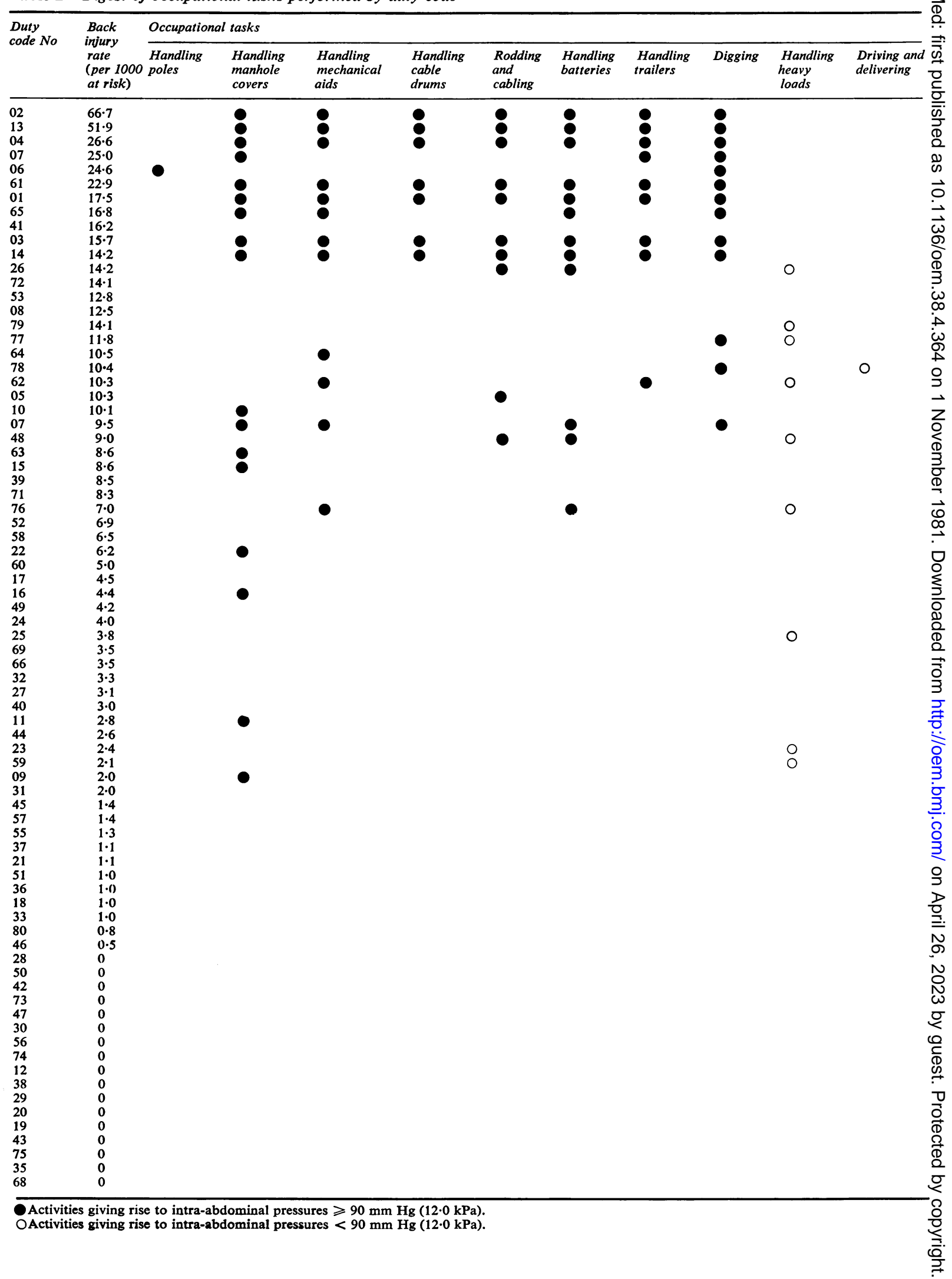




\begin{tabular}{|c|c|c|c|c|c|c|c|c|c|c|c|}
\hline $\begin{array}{l}\text { Handling } \\
\text { ladders }\end{array}$ & $\begin{array}{l}\text { Wiring } \\
\text { joints }\end{array}$ & $\begin{array}{l}\text { Over- } \\
\text { head } \\
\text { cabling }\end{array}$ & $\begin{array}{l}\text { Brick- } \\
\text { laying }\end{array}$ & $\begin{array}{l}\text { Working } \\
\text { up poles } \\
\& \text { masts }\end{array}$ & $\begin{array}{l}\text { Tree } \\
\text { cutting }\end{array}$ & $\begin{array}{l}\text { Lifting } \\
\text { light } \\
\text { equipment }\end{array}$ & $\begin{array}{l}\text { Light } \\
\text { cabling }\end{array}$ & $\begin{array}{l}\text { Exchange } \\
\text { wiring }\end{array}$ & $\begin{array}{l}\text { Domestic } \\
\text { wiring }\end{array}$ & Surveying & Clerical \\
\hline $\begin{array}{l}\circ \\
\text { O } \\
0\end{array}$ & & & 0 & 0 & & & & & & & \\
\hline 웅 & & & $\begin{array}{l}0 \\
0\end{array}$ & ○ & & & & & & & \\
\hline $\begin{array}{l}\text { O } \\
\text { O } \\
\text { O }\end{array}$ & 0 & 0 & 0 & $\begin{array}{l}0 \\
0\end{array}$ & & 0 & 0 & 0 & & & \\
\hline $\begin{array}{l}0 \\
0\end{array}$ & & & & & & $\begin{array}{l}\circ \\
\circ\end{array}$ & & $\begin{array}{l}0 \\
0\end{array}$ & 0 & & 0 \\
\hline & & & & & & 0 & & & & & O \\
\hline 0 & & & & 0 & & & & & & 0 & \\
\hline $\begin{array}{l}\text { O } \\
\text { O }\end{array}$ & & 0 & & $\begin{array}{l}\circ \\
\circ\end{array}$ & 0 & & & & & 0 & \\
\hline $\begin{array}{l}\text { O } \\
\text { O }\end{array}$ & 0 & 0 & & 0 & & & 0 & & & 0 & O \\
\hline $\begin{array}{l}\text { O } \\
\text { O } \\
\text { O }\end{array}$ & & $\begin{array}{l}\circ \\
\mathrm{O}\end{array}$ & & $\begin{array}{l}0 \\
\text { O }\end{array}$ & & $\begin{array}{l}\circ \\
\circ \\
\circ\end{array}$ & & 0 & O & & 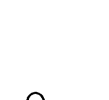 \\
\hline $\begin{array}{l}0 \\
0\end{array}$ & & 0 & & 0 & & $\begin{array}{l}\circ \\
\circ\end{array}$ & & 0 & & & \\
\hline 0 & & & & & & 0 & & $\stackrel{\circ}{\circ}$ & 0 & 0 & 0 \\
\hline $\begin{array}{l}0 \\
0\end{array}$ & & 0 & & 0 & & & & & 0 & & 0 \\
\hline & 0 & & & & & & & 0 & & & 0 \\
\hline O & 0 & & & & & & & 0 & 0 & & 0 \\
\hline o & & & & & & 0 & & 0 & & 0 & 0 \\
\hline 0 & & & & & & 0 & & 0 & & & O \\
\hline b & & 0 & & 0 & & ○ & & ○ & & & 0 \\
\hline b & & & & & & ○ & & 응 & & & $\begin{array}{l}0 \\
0\end{array}$ \\
\hline D & & & & & & $\begin{array}{l}\circ \\
\circ \\
\circ\end{array}$ & & $\begin{array}{l}\circ \\
\circ \\
\circ\end{array}$ & & & ㅇ \\
\hline 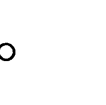 & & & & & & ○ & & ○ & & & O \\
\hline D & & & & & & ○ & & 0 & & & $\begin{array}{l}0 \\
\circ \\
\circ \\
0\end{array}$ \\
\hline 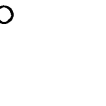 & & & & & & 웅 & & ○ & & & $\underset{v}{\circ} \bigcirc$ \\
\hline
\end{tabular}


Table 3 Comparison between accident rates for light and heavy occupations within the telecommunications and construction industries

\begin{tabular}{|c|c|c|c|c|}
\hline \multirow[t]{3}{*}{ Accident category } & \multicolumn{4}{|c|}{ Accident rate (per 1000 at risk) } \\
\hline & \multicolumn{2}{|l|}{ Light occupations } & \multicolumn{2}{|l|}{ Heavy occupations } \\
\hline & Telecomms industry & Construction industry & Telecomms industry & Construction industry \\
\hline $\begin{array}{l}\text { All accidents } \\
\text { Handling accidents } \\
\text { Back injuries } \\
\text { Back injuries } \\
\text { attributed to handling } \\
\text { incidents }\end{array}$ & $\begin{array}{r}10 \cdot 4^{*} \\
3 \cdot 0^{*} \\
2 \cdot 3^{*}\end{array}$ & $\begin{array}{r}32 \cdot 3^{*} \\
5 \cdot 2^{*} \\
6 \cdot 2^{*}\end{array}$ & $\begin{array}{l}46 \cdot 9 \\
16 \cdot 0 \\
12 \cdot 3\end{array}$ & $\begin{array}{l}58 \cdot 4 \\
15 \cdot 6 \\
13 \cdot 2\end{array}$ \\
\hline
\end{tabular}

* Level of significance between occupational groups $p<0.05$.

table. In addition, where the same activities were performed under different environmental conditions or where two or more items of equipment or different models were used, the IAP measurements have been grouped separately for comparative purposes.

From this information and a knowledge of the job descriptions and activities of each of the 79 duty codes, it was possible to compile a digest of occupational tasks performed by duty codes as shown in table 2 . The duty code groups are ranked from top to bottom in order of decreasing back injury rate as calculated from the analysis of accident returns described elsewhere. ${ }^{12}$ For each duty code the occupational tasks performed are marked by either a dot or a circle as explained in the footnotes to the table. The tasks listed are ranked from left to right in order of decreasing mean intra-abdominal pressure as presented in table 1. For simplicity, the tasks "water pump and generator handling" and "air bottle and gas bottle handling" have been regrouped in table 2 under the title "handling mechanical aids." Other tasks listed in table 2, but without corresponding data in table 1 , have either been included based on the results of field studies in other industries or have been nominally assigned IAP values based on the physical labour content of the task in relation to the other activities.

The accident rates of all accidents, handling

Table 4 List of 11 duty codes with the highest back injury rates

\begin{tabular}{ll}
\hline Duty code & $\begin{array}{c}\text { Back injury rate } \\
\text { (per 1000 at risk) }\end{array}$ \\
\hline Rodding and cabling (3-man party) & $66 \cdot 7$ \\
General purpose installation party & $51 \cdot 9$ \\
Rodding and cabling (2-man party) & 26.6 \\
Manhole box building & $25 \cdot 0$ \\
Pole erection unit & $24 \cdot 6$ \\
External general purpose maintenance & $22 \cdot 9$ \\
Cabling in ducts & $17 \cdot 5$ \\
Maintenance jointers & 16.8 \\
Maintenance transmission equipment & $16 \cdot 2$ \\
General purpose external party & $15 \cdot 7$ \\
Installation jointers & $14 \cdot 2$ \\
\hline
\end{tabular}

accidents, back injuries, and back injuries attributed to handling incidents for the light and heavy occupations of the telecommunications and construction industries are presented in table 3 . In this context heavy occupations in the telecommunications industry refer to the top 23 duty codes, and in the construction industry to such trades as roofing tilers and labourers. ${ }^{10}$ Light occupations refer to the remaining 56 duty codes in the telecommunications industry and trades, such as carpenters, painters, and drivers in the construction industry. When the industrial groups were compared, the accident rates of all four accident types for light, but not heavy, occupations were found to be significantly different.

Table 4 shows the 11 duty codes with the highest back injury rates. The 12 th duty code with a back injury rate greater than the mean back injury rate of the top 23 was a low population group incurring very few back injuries, and was therefore excluded from considerations specific to these groups of high risk duties.

\section{Discussion}

In previous studies investigating manual handling hazards in the building and construction industry, Stubbs and Nicholson ${ }^{10}$ found that the trades defined as heavy manual work had significantly higher back injury rates $(p<0.01)$ than the light occupations. Stubbs ${ }^{16}$ and Davis and Stubbs ${ }^{17}$ found that the work of the operatives comprising the heavy occupations included a high proportion of frequent, heavy lifts giving rise to IAPs in excess of $100 \mathrm{~mm} \mathrm{Hg}(13.3 \mathrm{kPa})$. Operatives in the light occupations were found to handle loads less frequently; those loads which were handled rarely resulted in IAPs exceeding $60 \mathrm{~mm} \mathrm{Hg}(8.0 \mathrm{kPa})$. Thus there appears to be an increased liability to back injuries caused by load handling in those workers in the construction industry sustaining repeated, frequent high trunk stresses inducing peak IAPs in excess of $100 \mathrm{~mm} \mathrm{Hg}(13.3 \mathrm{kPa})$. From later laboratory 
studies 1819 it was considered necessary to regardithe value of IAP of $90 \mathrm{~mm} \mathrm{Hg}(12.0 \mathrm{kPa})$ as "safe" for British male industrial workers.

Since it has been shown (table 3) that the trades defined heavy occupations in the construction industry cannot be distinguished from the top 23 duty codes of the telecommunications industry, the hypothesis that $90 \mathrm{~mm} \mathrm{Hg}(12.0 \mathrm{kPa})$ can be regarded as a criterion for safe manual handling, and that repeated, frequent high trunk stresses give rise to an increased liability to back injury can be rigorously assessed.

Several observations may be made from table 2 . It is first apparent that a relationship exists between the incidence of back injury and the manual handling content of the various duties. The 11 duties with the highest back injury rates (table 4) may be seen to carry out a high proportion of manual handling tasks, particularly those that are more physically demanding and which give rise to IAPs in excess of $90 \mathrm{~mm} \mathrm{Hg}(12.0 \mathrm{kPa})$ and result in high mean IAPs. All 11 of these duty codes are included in the top 23.

The next group of 18 duty codes with back injury rates from 14.2 to 7.0 per 1000 at risk range from works control engineers and pole testing gangs to one-man telephone installers and maintenance gangs. These duties require a mixed range of handling activities. Fewer than $40 \%$ of the occupational tasks carried out by these duties gave rise to IAPs in excess of $90 \mathrm{~mm} \mathrm{Hg}(12.0 \mathrm{kPa})$ compared with $71 \%$ for the first group. Seven of these duty codes are included in the top 23.

The remaining duty codes have back injury rates ranging from 6.9 to 0 per 1000 at risk. Of all the tasks performed, only four $(4 \%)$ were found to give rise to high truncal stresses. These groups are predominantly of a sedentary nature, being largely supervisory staff, rarely required to perform manual handling tasks. Only five of these duty codes are included in the top 23.

The frequency with which the tasks are carried out can be summarised in the following manner. The manhandling of poles, cable drums, and trailers is performed by specific duty codes at infrequent intervals throughout the day except in exceptional circumstances. Rodding and cabling, although also performed by specific duty codes, are carried out much more frequently, tending to be undertaken in bursts of activity, the timing of which is governed by the engineers themselves. Handling covers and joint boxes, mechanical aids, and digging are tasks frequently carried out during the day, as are ladder handling and lifting light unspecified equipment. The remaining activities are all specific to certain duty codes. Except in the few instances where these activities are fundamental descriptions of the occupation the engineers perform, these tasks are carried out infrequently during the day.

Clearly, therefore, those groups of workers with the highest back injury rates carry out the greatest proportion of handling tasks. Of these, most (71\%) give rise to IAPs in excess of $90 \mathrm{~mm} \mathrm{Hg}(12 \cdot 0 \mathrm{kPa})$. Conversely, those groups with the lowest back injury rates carry out manual handling tasks less frequently, and a small proportion $(4 \%)$ of these induce pressures greater than $90 \mathrm{~mm} \mathrm{Hg}(12 \cdot 0 \mathrm{kPa})$. By examining table 1 it can be seen that the remaining $96 \%$ of the tasks carried out in this group give rise to IAPs below $50 \mathrm{~mm} \mathrm{Hg}(6.7 \mathrm{kPa})$. The middle group of 18 duty codes consists of duties demanding a mixed spread of activities with a correspondingly varied handling component and frequency.

These results confirm the observations made in the construction industry - that there appears to be an increased liability to back injury in workers performing a high proportion of frequent, heavy lifts inducing IAPs in excess of $90 \mathrm{~mm} \mathrm{Hg}(12.0 \mathrm{kPa})$. In addition, they add support to the argument that there is a close correlation between the manual handling content of an occupation and the appearance of back disorders.

Davis and Sheppard ${ }^{12}$ found that back injuries attributed to handling incidents in the telecommunications industry occur most frequently in the 31-45 year age group and that $93 \%$ of all accidents occur after the first year of employment. In the construction industry, however, ${ }^{10}$ the $28-39$ year olds suffer less frequently from back injuries attributed to handling incidents than 16-18 year olds. These observations support the argument proposed by Jackson $^{20}$ and others 2122 that two types of back injury can occur. Firstly, those in which the forces of insult are great enough to produce acute trauma without the involvement of secondary predisposing factors and, secondly, those in which degeneration of the spine is hastened by the superimposition of long-term effects of load handling on other factors gradually leading to cumulative damage. Apprentices in the construction industry rarely receive any instruction in correct methods of manual handling and are at greatest risk of suffering acute back injuries. ${ }^{10}$ Apprentice telecommunications engineers, however, undergo a four-year training during which time they are carefully instructed and supervised. The pattern of accident distribution for telecommunications engineers tends to suggest that they suffer more from degenerative back disorders in their middle ages and survive early acute injury because of their training. Similarly, the 28-39 year olds in the construction industry are most probably those who have survived early acute injury but suffer from the cumulative effects of load handling leading to back 
disorders through degeneration of the spine.

Davis and Sheppard ${ }^{12}$ also found that in studying the age distribution of the top 23, the younger engineers have a relatively higher back injury rate. As discussed, the occupations comprising the top 23 carry out a high proportion of tasks giving rise to high levels of IAP. It would appear, therefore, that by carrying out these frequent manual handling tasks they are at risk of an earlier onset of degenerative disorders since the load handling is not so frequent or extreme as to cause acute injury but is sufficient to promote degeneration. An earlier onset of low back pain in occupations performing heavy manual work is also reported by Magora and Taustein, ${ }^{9}$ Hult, ${ }^{3}$ and Anderson et al..$^{23}$

In addition to heavy and frequent lifting and carrying, two other occupational factors were recognised during field studies as contributing to the degenerative processes in the spine.

Ten of the 12 duty codes found to incur back injury rates greater than the mean back injury rate of the top 23 work out of doors throughout the year, where they are exposed to both wet and cold conditions. Lawrence ${ }^{24}$ and Kellgren et $\mathbf{l}^{25}$ reported that such conditions increase the incidence of symptoms of degenerative back disease. In considering the contradictory evidence that is also reported, Wickstrom ${ }^{11}$ suggested that wet and cold work conditions may merely awake or aggravate existing degenerative and rheumatic symptoms.

Incorrect working postures were often encountered, particularly those associated with heavy lifting activities. The stoop lift, known to induce high trunk stresses, was commonly observed. ${ }^{15}$ In certain duty codes, notably jointers, prolonged periods of stooping were a common sight. Postural fatigue induced by this practice is recognised as an important element in the production of low back pain. ${ }^{26-30}$

In the eight occupational tasks identified as giving rise to IAPs in excess of $90 \mathrm{~mm} \mathrm{Hg} \mathrm{(12.0}$ $\mathrm{kPa}$ ) (table 2) it was found that the truncal stresses incurred while performing the tasks could be reduced by modifying lifting postures and techniques or by altering the design of certain tools and pieces of equipment. For example, in rodding and cabling activities, kneeling or squatting eradicates any necessity for stooping and substantially reduces the IAP(table 1); two men handling water pumps instead of one produces a similar reduction (table 1). Specific measures to reduce back strain can be simply made once the stressful occupational factors have been identified.

We thank the Post Office Telecommunications branch (British Telecom), for whom this work was carried out under contract, and the willing and helpful volunteers who participated in the study.

\section{References}

${ }^{1}$ Wood PHN, Badley EM. The epidemiology of back pain. In: Jayson M, ed. The lumbar spine and back pain. 2nd ed. Tunbridge Wells, Kent: Pitman Press, 1980:29-55.

${ }^{2}$ Hult L. The Monkfors investigation. Acta Orthop Scand 1954 ;suppl 16.

${ }^{3}$ Hult L. Cervical, dorsal and lumbar spine syndromes. Acta Orthop Scand 1954 ;suppl 17.

4 Lawrence JS, Aitken-Swan J. Rheumatism in miners. Part I Rheumatic complaints. Br J Ind Med 1952;9:1-18.

${ }^{5}$ Anderson JAD, Duthie JJR. Rheumatic complaints in dockyard workers. Ann Rheum Dis 1963;22:401-9.

- Ikata T. Statistical and dynamic studies of lesions due to overloading on the spine. Shikoku Acta Medica 1965; 40:262. (English abstract.)

? Partridge REH, Anderson JAD, McCarthy MA, Duthie JJR. Rheumatism in light industry. Ann Rheum Dis 1965 ; 24:332-40.

${ }^{8}$ Lawrence JS. Disc degeneration: its frequency and relationship to symptoms. Ann Rheum Dis 1969;28: 121-37.

9 Magora A, Taustein I. An investigation of the problem of sick leave in the patient suffering from low back pain. Industrial Medicine and Surgery 1969;38:398-408.

${ }^{10}$ Stubbs DA, Nicholson AS. Manual handling and back injuries in the construction industry: an investigation. Journal of Occupational Accidents 1979;2:179-90.

${ }^{11}$ Wickstrom G. Effect of work on degenerative back disease: a review. Scand J Work Environ Health 1978; suppl 1:1-12.

12 Davis PR, Sheppard NJ. The pattern of accident distribution in the telecommunications industry. $\mathrm{Br} \mathrm{J}$ Ind $\mathrm{Med}$ $1980 ; 37: 175-9$.

13 Davis PR. Variations of intra-abdominal pressure during weight lifting in various postures. $J$ Anat 1956;90:601 (P).

14 Morris JM, Lucas DB, Bresler B. The role of the trunk in stability of the spine. J Bone Joint Surg 1961;43A:327-51.

${ }^{15}$ Davis PR, Stubbs DA, Ridd JE. Radio pills: their use in monitoring back stress. J Med Eng Technol 1977;1: 209-12.

16 Stubbs DA. Trunk stresses in construction workers. Guildford: University of Surrey, 1975. (PhD Thesis.)

17 Davis PR, Stubbs DA. A method of establishing safe handling forces in working situations. Washington: DHEW, 1978:34-8. (DHEW (NIOSH) Pub No 78-185.)

18 Davis PR, Stubbs DA. Safe levels of manual forces for young males. 1, 2, and 3. Applied Ergonomics 1977; 8:141-50, 8:219-28,1978;9:33-7.

19 Materials Handling Research Unit. Force limits in manual work. Guildford, Surrey: IPC Science and Technology Press Ltd, 1980.

20 Jackson JM. Biomechanical hazards in the dockworker. Ann Occup Hyg 1968;11:147-57.

21 Mehnert E. Degenerative Veranderungen durch statische Fehlbelastung beiden Einglegerinnen der Baumwollspinnerereinen-eine vermedbare Schadigung der Wirbesaule. Deutsche Gesundheitswesen 1969;24:1716-21.

22 Schmorl G. Uber Knorpelknotchen an der Wirbelbandscheiben. ROEFO 1928;38:265-79.

23 Anderson JAD, Duthie JJR, Moody BP. Social and economic effects of rheumatic diseases in a mining population. Ann Rheum Dis 1962;21:342-51.

${ }^{24}$ Lawrence JS. The influence of climate on rheumatic complaints. In: Rheumatism in populations. London: William Heinemann Medical Books Ltd, 1977:505-18. 
${ }^{25}$ Kellgren JH, Lawrence JS, Aitken-Swan J. Rheumatic complaints in an urban population. Ann Rheum Dis 1953; 12:5-15.

26 Troup JDG. Relation of lumbar spine disorders to heavy manual work and lifting. Lancet $1965 ; \mathrm{i}: 857-61$.

${ }^{27}$ Brown JR. Lifting as an industrial hazard. Am Ind Hyg Assoc J 1973;34:292-7.

${ }^{38}$ Lawrence JS. Rheumatism in coal miners: Part III

Occupational factors. Br J Ind Med 1955;12:249-61.

29 Partridge REH, Anderson JAD, McCarthy MA, Duthie JJR. Rheumatic complaints among workers in iron foundries. Ann Rheum Dis 1968;27:441-52.

${ }^{30}$ Sarri JS, Wickstrom G. Load on back in concrete reinforcement work. Scand J Work Environ Health 1978; 4,suppl 1:13-9. 